\title{
Питання психології
}

УДК 159.9:355

DOI: $10.33099 / 2617-6858-20-56-3-102-111$

Сиропятов О. Г. доктор медичних наук, професор, Державна установа "Науково-дослідної установи Міністерства охорони здоров'я України” https:// orcid.org/0000-0002-1177-3127

Дзеружинська Н. О. доктор медичних наук, професор, Начіональний медичний університет імені О.О. Богомольия https:// orcid.org/0000-0003-0427-7472

Шемчук О. М. Українська військово-медична академія https:// orcid.org/0000-0002-0641-0313

Марущенко К. Ю. Українська військово-медична академія https:// orcid.org/0000-0001-5411-6912

\section{КОНЦЕПЦІЯ МЕДИКО-ПСИХОЛОГІЧНОГО СУПРОВОДУ ВІЙСЬКОВОСЛУЖБОВЦІВ ЗБРОЙНИХ СИЛ УКРАЇНИ}

У статті розглянуто конщепцію медико-психологічного супроводу військовослужбовиів Збройних Сил Украӥни. Зміст медико-психологічного супроводу полягає у виявленні, аналізі, оцінюванні динаміки соиіально-психологічного клімату у військових колективах, безпосередньому спостереженні за психічним станом військовослужбовиів, наданні медико-психологічної допомоги у складних психологічних умовах проходження військової служби, спостереженні та корегуванні соціальнопсихологічними прочесами у військових колективах.

Ключові слова: медико-психологічний супровід; сочіально-психологічний клімат; клінікопсихологічний відбір; військовослужбовиі.

Постановка проблеми. Підтримка психічного здоров'я військовослужбовців $€$ найважливішим соціальним та медичним спільним завданням Командування медичних сил Збройних Сил України. Сучасні події у державі свідчать про те, що психологічне здоров'я військовослужбовців як в мирний, так і військовий час, $\epsilon$ не тільки медичною, а i соціально-психолого - психіатричною проблемою [1].

Сучасні умови проходження служби у військових формуваннях орієнтовані на стандарти НАТО, які передбачають наявність у військовослужбовців не лише стійких психологічних якостей, а і високого рівня інтелектуальних здібностей, фізичної тренованості та можливості швидко та якісно засвоювати навички оволодіння новими військовими спеціальностями та розвивати їх в стислий проміжок часу в екстремальних умовах.

Дефіцит комплектування ЗС України особовим складом за наявності складних економічних, морально-психологічних, політичних проблем в Україні ставить питання щодо збереження психічного здоров'я військовослужбовців та їх медикопсихологічного супроводу під час проходженні військової служби у різних військових формуваннях.
Дослідження науковців [А. Плотнікова, А. Гахова, В. Коваленка], які вивчали причини звільнення військовослужбовців 3 лав ЗС України за станом здоров'я свідчать про те, що приблизно 40\% призовників та солдат щорічно визнані непридатними та звільнені з лав ЗС України у зв'язку із наявністю у них психічних розладів [2]. В структурі психічної патології у них невротичні розлади та розлади особистості займають найбільшу частку. Данні аналізу епідеміологічних даних захворюваності призовників та солдат строкової служби, яких було госпіталізовано із різноманітними невротичними проявами до психіатричного відділення ГВМКЦ м. Києва за останні п’ять років, підтверджую актуальність і значимість необхідності диференціювання рівнів психічної дезадаптації з метою проведення психокорекційної та психопрофілактичної роботи у військах (силах) [3].

Слід зазначити, що найбільшого загострення проблема збереження психічного здоров'я військовослужбовців та мирних громадян, які проживають на тимчасово окупованих територіях, i це відображено у доповідях ВООЗ, набула під час участі військовослужбовців ЗС України в ООС/АТО на сході України. Практично в усіх осіб перерахованого контингенту було діагностовано різні за проявом та ступенем 


\section{Питання психології}

тяжкості прояви посттравматичного стресового розладу [4].

Метою дослідження є: розроблення та обгрунтування концепції медикопсихологічного супроводу військовослужбовців 3 метою профілактики виникнення та прогресування психічних розладів у військовослужбовців ЗС України.

$$
\text { Медико-психологічний супровід }
$$
військовослужбовців - міждисциплінарна динамічна система соціальних та медикопсихологічних дій, спрямована на адаптацію військовослужбовців до умов проходження військової служби у різних військових формуваннях, в мирний та військовий час. Завдяки ньому відбувається не лише своєчасне надання медико-психологічної допомоги у кризових військово-професійних ситуаціях, a $\mathrm{i}$ опанування військовослужбовцями навичок надання психологічної само- та взаємодопомоги в екстремальних (нестандартних, напружених) умовах, що підвищує їх стресостійкість, професійну адаптивність, психологічну витривалість та акумулює психологічний ресурс особистості військовослужбовця [5].

Початковим етапом медикопсихологічного супроводу, на нашу думку, є проходження кандидатами на військову службу психологічного відбору та визначення їх придатності військоволікарськими комісіями військових комісаріатів, тому що саме від вихідних психолого-адаптивних характеристик особистості майбутніх військовослужбовців залежить їх подальше психологічне благополуччя.

Виокремимо основні завдання професійно-психологічного відбору (ППВ):

1. Визначення базових психологічних характеристик та професійно важливих якостей призовників, необхідних для проходження ними військової служби;

2. Дослідження індивідуальноособистісних якостей майбутніх військовослужбовців з метою спрямування їх “вектору професіоналізаціi” до опанування ними тією чи іншою військовою спеціальністю;

Основними напрямками ППВ є:

визначення професійних психологічних вимог до майбутніх військовослужбовців;

психологічне вивчення кандидатів та підготовка відповідних висновків на основі вивчених психологічних вимог до професійної діяльності; розробка рекомендацій ПО комплектуванню підрозділів 3 урахуванням психологічної сумісності військовослужбовців, призначення молодших командирів i формуванні групи уваги [6].

Після обробки отриманих в ході ППВ результатів психолог робить висновки про придатність кандидатів до окремих військових спеціальностей за IV категоріями: I - рекомендовано у першу чергу, повністю відповідає обраній спеціальності; II - в основному відповідає; III - мінімально відповідає, допускається за відсутності інших кандидатів; IV - не відповідає i не рекомендується для опанування обраною військовою спеціальністю.

В ході проведення ППВ зазвичай використовують наступні тестові методики:

1. «S-test» - графічний субтест, що використовується 3 метою зорового сприйняття, уваги, здатності до ідентифікування об'єктів в умовах обмеженого часу. Методика використовується для оцінки здатності оперування просторовими образами і темпу розумових операцій [7];

2. Короткий відбірковий тест B.M. Бузіна - Е.Ф. Вандерліка - використовують 3 метою оцінки загального рівня розумових здібностей, вербального та невербального інтелекту, здатності до узагальнення й аналізу, гнучкості мислення, здатності до переключення, точності i швидкості сприйняття, емоційного компоненту.

3. Професійно-особистісний опитувальник В.П. Петрова використовується для визначення військовопрофесійної спрямованості кандидатів на проходження військової служби та виокремлення у них здібностей до окремих військових спеціальностей (командних, операторських, зв'язку i спостереження, водійських, спеціального призначення (спецназ)) [8];

4. Анкета «Прогноз» за В.А. Бодровим розроблена для початкового орієнтовного виявлення осіб з ознаками нервово-психічної нестійкості. Дозволяє виявити окремі початкові симптоми порушень особистості, а також оцінити вірогідність їх розвитку й прояву в поведінці та діяльності людини;

Після комплексного опрацювання результатів проведеного тестування, за допомогою методик, наведених вище, психолог формулює висновок про 


\section{Питання психології}

особистість призовника, його емоційність та когнітивні особливості. Етапу психологічного відбору слід приділяти ретельну увагу ще й тому, що у 70-85\% військовослужбовців в загальній структурі психічної захворюваності зустрічаються психогенно обумовлені розлади, які в подальшому виступають провокуючими чинниками звільнення військовослужбовців 3 лав ЗС України за станом здоров'я [9].
Наступним кроком виключення ризиків виникнення у майбутніх військовослужбовців психічних розладів $\epsilon$ проведення медико-психологічного відбору, який здійснюється шляхом проведення напівструктурованого клінічного інтерв'ю за допомогою попереднього оцінювання стану психічного здоров'я кандидатів методом виключення клінічних симптомів [7; 10; 11], наведених у табл. 1.

Таблиия 1

Порушення психічного здоров'я: клінічні симптоми та визначення

\begin{tabular}{|c|c|c|}
\hline $\begin{array}{l}\text { № } \\
\text { 3/ח } \\
\end{array}$ & $\begin{array}{l}\text { Клінічний } \\
\text { симптом }\end{array}$ & Визначення \\
\hline 1. & апатія & $\begin{array}{l}\text { клінічний симптом, який характеризується байдужим ставленням до } \\
\text { довкілля, зникненням зовнішніх проявів емоційних реакцій. } \\
\text { звичайним проявом депресії, шизофренії, різних соматичних } \\
\text { неврологічних станів. }\end{array}$ \\
\hline 2. & аутизація & $\begin{array}{l}\text { зменшення потреби у спілкуванні, погіршення контактів з оточенням. } \\
\text { Проявляється у хворих на аутизм шизофренію, депресивні розлади, у } \\
\text { здорових людей в стресовій ситуації, }\end{array}$ \\
\hline 3. & $\begin{array}{l}\text { вегетативні } \\
\text { розлади }\end{array}$ & $\begin{array}{l}\text { об'єднує різноманітні за походженнями і проявами розлади } \\
\text { вегетативних функцій організму, що зумовлені порушенням їх } \\
\text { нейрогенної регуляції. В основі патогенезу вегетативної дисфункції } \\
\text { лежить порушення інтегративної діяльності надсегментарних } \\
\text { вегетативних структур (лімбікоретикулярного комплексу), в результаті } \\
\text { чого розвивається дезінтеграція вегетативних, емоційних, } \\
\text { сенсомоторних, ендокринно-вісцеральних співвідношень, а також } \\
\text { циклу сон - активність. }\end{array}$ \\
\hline 4. & $\begin{array}{l}\text { відкритість } \\
\text { думок }\end{array}$ & $\begin{array}{l}\text { психопатологічний симптом, що виражається у впевненості індивіда в } \\
\text { тому, що всі оточуючі можуть підслуховувати чи ідентифікувати іншим } \\
\text { шляхом його думки. }\end{array}$ \\
\hline 5. & гіперестезія & $\begin{array}{l}\text { підвищена чутливість до подразників, коли звичайні відчуття } \\
\text { набувають різкого характеру. В такому випадку незначні подразники, } \\
\text { які раніше сприймались як перед порогові, сприймаються як значні. } \\
\text { Може спостерігатись при тривозі, астенії, соматоформних вегетативних } \\
\text { розладах, деменції. }\end{array}$ \\
\hline 6. & гіпотимія & $\begin{array}{l}\text { стійке зниження настрою, яке супроводжується зменшенням } \\
\text { iнтенсивності емоційної, психічної та інколи рухової активності. } \\
\text { Спостерігається при циклотимії та пограничних психічних станах. Є } \\
\text { однією } 3 \text { ознак депресивного синдрому, характерна для астенії та } \\
\text { хронічної шизофренії. }\end{array}$ \\
\hline 7. & диссомнії & $\begin{array}{l}\text { розлади сну, що характеризуються недостатньою кількістю чи якістю } \\
\text { сну або поєднанням цих патологічних явищ впродовж тривалого } \\
\text { проміжку часу. В такому разі абсолютна тривалість(кількість годин } \\
\text { сну) не мають вирішального значення, тому що у різних людей так } \\
\text { звана нормальна тривалість сну може відрізнятися. Зустрічається у } \\
\text { пацієнтів із депресією, тривожними розладами. }\end{array}$ \\
\hline 8. & $\begin{array}{l}\text { емоційна } \\
\text { слабкість }\end{array}$ & $\begin{array}{l}\text { стан, що характеризується астенічністю (слабкістю, безсиллям) } \\
\text { емоційних проявів, які пригнічують людину, послаблюють їі } \\
\text { активність, демобілізують викликають страждання та зневіру. } \\
\text { Характерна для депресії, неврастенії, нав'язливих думок, істерії, } \\
\text { психозу, тощо }\end{array}$ \\
\hline 9. & $\begin{array}{l}\text { емоційна } \\
\text { лабільність }\end{array}$ & $\begin{array}{l}\text { це коливання настрою; легкі переходи від благодушності до гнівливого } \\
\text { чи пригніченого стану. Характеризується схильністю особистості до } \\
\text { бурхливих реакцій: гніву, агресії, швидких і частих змін полярності } \\
\text { емоцій, які виникають без достатньої підстави. Може вказувати на }\end{array}$ \\
\hline
\end{tabular}




\section{Питання психології}

\begin{tabular}{|c|c|c|}
\hline & & $\begin{array}{l}\text { наявність депресії, неврастенії, нав'язливих думок, істерії, психозу, } \\
\text { тощо. }\end{array}$ \\
\hline 10. & іпохондрія & $\begin{array}{l}\text { Клінічний синдром, що проявляється в постійному занепокоєнні } 3 \\
\text { приводу можливості захворіти на одну або декілька хвороб, скаргах або } \\
\text { заклопотаності своїм фізичним здоров'ям, сприйнятті звичайних } \\
\text { відчуттів як ненормальних і неприємних, у припущеннях, що окрім } \\
\text { основного захворювання є якесь додаткове. При цьому людина може } \\
\text { вважати, що знає, яке у неї «насправді» захворювання, але міра його } \\
\text { переконаності з цього приводу зазвичай раз від разу змінюється, і вона } \\
\text { вважає імовірнішим то одне захворювання, то інше, тобто маніпулює } \\
\text { ними. Зустрічається у людей, що страждають на сенесто-іпохондричну } \\
\text { депресію }\end{array}$ \\
\hline 11. & $\begin{array}{l}\text { нав'язливі } \\
\text { думки } \\
\text { (обсесії) }\end{array}$ & $\begin{array}{l}\text { це повторювані думки, бажання, образи, що бентежать. Наприклад } \\
\text { страх зараження чи забруднення, небажані чи табуйовані думки про } \\
\text { секс, релігію чи травмування себе або інших, агресивні думки про себе } \\
\text { чи інших, та бажання все симетрично або досконало впорядкувати. } \\
\text { Обсесії зустрічаються у людей, що страждають на обсесивно- } \\
\text { компульсивні розлади, дисморфічне порушення, депресивні розлади. }\end{array}$ \\
\hline 12. & надцінні ідеї & $\begin{array}{l}\text { судження, які виникають у особистості в реальних життєвих } \\
\text { обставинах, базуютья на її світогляді, але мають домінантне значення } \\
\text { над іншими думками і супроводжуються значною емоційною } \\
\text { напругою. Людину охоплює надмірна наполегливість у досягненні } \\
\text { задуманої мети. Надцінні ідеї можуть виникати як при розладах } \\
\text { особистості так і у осіб психопатів гіпертимного складу, у хворих на } \\
\text { шизофренію чи афективні психози. }\end{array}$ \\
\hline 13. & $\begin{array}{l}\text { обмани } \\
\text { сприйняття }\end{array}$ & $\begin{array}{l}\text { відносять ілюзії та галюцинації. Ілюзії - розлади, при яких індивід } \\
\text { сприймає реально існуючі об'єкти і предмети як зовсім інші. } \\
\text { Галюцинації - розлади сприйняття, при яких об'єкти і явища } \\
\text { уявляються там, де їх в дійсності немає. Характерні для деліріозного } \\
\text { стану, шизофренії, бредових станів. }\end{array}$ \\
\hline 14. & $\begin{array}{l}\text { паранояльні } \\
\text { ідеї }\end{array}$ & $\begin{array}{l}\text { розлад, який характеризується порушенням мислення і проявляється їх } \\
\text { надмірною мнимістю та підозрілістю. Такі ідеї зустрічаються у } \\
\text { пацієнтів, які страждають на алкоголізм, наркоманію, атеросклероз } \\
\text { церебральних судин, хворобу Альцгеймера тощо. }\end{array}$ \\
\hline 15. & $\begin{array}{l}\text { пароксизмаль } \\
\text { ні розлади }\end{array}$ & $\begin{array}{l}\text { зустрічаються при захворюваннях нервової системи, які проявляються } \\
\text { у вигляді нападів (пароксизмів) - це і мігренозні атаки (нападоподібні } \\
\text { болісні головні болі, що починаються в одній половині голови), i } \\
\text { непритомність, що виникають при різних інших хворобах, } \\
\text { запаморочення при хворобі або синдромі Меньєра, і так звані } \\
\text { діенцефальні кризи або панічні атаки (вегетативні напади, що } \\
\text { супроводжуються підвищенням артеріального тиску, почастішанням } \\
\text { пульсу, страхом, вираженим занепокоєнням), і власне епілептичні } \\
\text { напади, які можуть протікати як з судомами - так і без них, як з втратою } \\
\text { свідомості - так і без неї. }\end{array}$ \\
\hline 16. & $\begin{array}{l}\text { порушення } \\
\text { активності та } \\
\text { уваги }\end{array}$ & $\begin{array}{l}\text { неврологічно-поведінковий синдром розладу розвитку, що починається } \\
\text { в дитячому віці. Проявляється такими симптомами, як труднощі } \\
\text { концентрації уваги, гіперактивністьі погано керована імпульсивність. } \\
\text { Зустрічаються у пацієнтів із неврозом, депресією, аутизмом. }\end{array}$ \\
\hline 17. & $\begin{array}{l}\text { розлади } \\
\text { потягів }\end{array}$ & $\begin{array}{l}\text { характеризуються непереборним прагненням, яке заволодіває хворим } \\
\text { усупереч здоровому глузду, почуттям і волі, виконати безглузді дії: } \\
\text { дромоматія, піроманія, клептоманія, міфоманія, арифмоманія, } \\
\text { дипсоманія, копролалія. Зустрічаються у психопатичних особистостей } \\
\text { при неврозі, на початку розвитку шизофренії. }\end{array}$ \\
\hline 18. & тривога & $\begin{array}{l}\text { різної вираженості тривога характеризується внутрішнім хвилюванням, } \\
\text { занепокоєнням про майбутні події, стисненням і напругою в грудях, } \\
\text { боязким очікуванням наближення лиха, песимістичними очікуваннями } \\
\text { подій в майбутньому. Тривога проявляється руховим неспокоєм, } \\
\text { непосидючістю тощо. Проявляється у хворих із різного роду }\end{array}$ \\
\hline
\end{tabular}




\section{Питання психології}

\begin{tabular}{|l|l|l|}
\hline & & $\begin{array}{l}\text { залежностями (алкогольною, наркотичною, тощо), тривожними } \\
\text { розладами, у здорових людей в стані сильного стресу, при ПТСР. }\end{array}$ \\
\hline 19. & фобії & $\begin{array}{l}\text { iрраціональний, інтенсивний і постійний страх, що виникає під } \\
\text { впливом певних ситуацій, дій, речей, тварин або людей. Основним } \\
\text { симптомом цього розладу є надмірне і необгрунтоване бажання } \\
\text { уникнути подразника, що відлякує. Неконтрольована фобія, яка заважає } \\
\text { повсякденному життю діагностуєтся як особистісний або психічний } \\
\text { розлад. Можуть зустрічатися при перевтомі, під впливом } \\
\text { психотравмуючої ситуації. }\end{array}$ \\
\hline
\end{tabular}

Для запобігання ризику виникнення суӥцидів у військових колективах, при проведенні клініко-психологічного відбору,

табл. 2.

Таблиия 2

Психічні стани, що насторожують на можливість виникнення суїциду

\begin{tabular}{|c|c|c|}
\hline $\begin{array}{l}\text { № } \\
\text { 3/ח }\end{array}$ & психічний стан & визначення \\
\hline 1. & $\begin{array}{l}\text { суїщидальна } \\
\text { ідеація }\end{array}$ & $\begin{array}{l}\text { початковий етап розвитку суїцидальної поведінки, що включає в } \\
\text { себе думки про самогубство та початкові прояви суїцидальних } \\
\text { тенденцій у вигляді їх нав'язливості. Передумовою виникнення } \\
\text { суїцидальних ідеацій вважаються антивітальні переживання. } \\
\text { Прикладами таких переживань можуть слугувати думки про } \\
\text { відсутність цінності та сенсу життя. У своєму розвитку } \\
\text { суїцидальні ідеації проходять через три основні етапи: пасивні } \\
\text { суїцидальні думки, замисли та наміри. }\end{array}$ \\
\hline 2. & $\begin{array}{l}\text { суїщидальні спроби } \\
\text { (діï) у родині }\end{array}$ & бажання та намагання людини щодо припинення власного життя. \\
\hline 3. & $\begin{array}{l}\text { самознищувальна } \\
\text { поведінка } \\
\text { (аутодеструктивна) }\end{array}$ & $\begin{array}{l}\text { поведінка, яка відхиляється від медичних і психологічних норм, } \\
\text { та загрожує цілісності і розвитку самої особи. Самознищувальна } \\
\text { поведінка в сучасному світі проявляється в наступних основних } \\
\text { формах: суїцидальна поведінка, харчова залежність, хімічна } \\
\text { залежність (зловживання психоактивними речовинами), } \\
\text { фанатична поведінка (наприклад, залученість в деструктивно- } \\
\text { релігійний культ), віктимна поведінка (поведінка жертви), } \\
\text { діяльність з вираженим ризиком для життя (екстремальні види } \\
\text { спорту, істотне перевищення швидкості під час їзді на автомобілі } \\
\text { тощо). }\end{array}$ \\
\hline
\end{tabular}

Сьогодні використовується багато інструментів і методів для оцінки ризику виникнення самогубства. Достовірні результати можна отримати при застосуванні (PHQ-9, Колумбійської шкала оцінювання тяжкості та самогубств - CSSRS).

Другим етапом медико-психологічного супроводу ми вважаємо роботу психологів та лікарів на пунктах прийому молодого поповнення. На даному етапі відбувається вивчення військовослужбовців, оцінювання ïx психологічного стану, індивідуальнопсихологічних та фізіологічних властивостей. Отримана інформація опосередковано вказує на адаптивність військовослужбовців до умов військової служби, визначає їх психологічну та емоційну стійкість. Ha цььому emani вивчення відповідальні особи опрацьовують списки військовослужбовців, які потребують додаткового медикопсихологічного обстеження.

Поглиблене

обстеження військовослужбовців із зазначеного списку проводять спільно психолог (фахівець морально-психологічного забезпечення) та лікар. Особливу увагу у процесі обстеження приділяють військовослужбовцям 3 ознаками нервово-психічної лабільності, проблемами адаптації до умов проходження служби; які не в змозі опанувати основні елементи бойової підготовки; що постійно порушують військову дисципліну чи самостійно звернулись за психологопсихіатричною допомогою. Сутність поглибленого обстеження військовослужбовців зазначених категорій полягає у цілісному вивченні їх особистості та виокремленні індивідуально- 


\section{Питання психології}

психологічних особливостей, які можуть бути тригерами виникнення кризових станів на особистісному та груповому рівнях. Результатом такого опрацювання $\epsilon$ утворення пропозицій та рекомендацій щодо корекції виявлених особливостей, індивідуалізації виховної роботи та навчання (підготовки).

Важливим аспектом відокремлення повноважень психіатра i психолога на даному етапі є розуміння того, що висновок про наявність у військовослужбовця нервово-психічної нестійкості дає психіатр, в той час як діяльність психолога при наданні психологічної допомоги військовослужбовцям ЗС України регламентована діагностикою їх об'єктивного стану, можливістю психологічного впливу та здійсненням психологічного супроводу.

Зупинимось окремо на основних напрямках роботи військового психолога:

Психопрофілактика - систематична, узгоджена робота психолога разом з іншими посадовими особами 3 попередження несприятливих психологічних явищ $\mathrm{y}$ військових колективах, між військовослужбовцями та членами їх сімей чи цивільним персоналом частини. Створення, підтримання та контроль сприятливих психологічних умов для підготовки, навчання, виховання військовослужбовців та недопущення виникнення у них психологічного перевантаження, надання психологічної підтримки військовослужбовцям, особливо у період їх адаптації до військової служби.

Психологічна корекиія - психологічний вплив на військовослужбовців, які мають відхилення від соціальної психічної норми 3 метою ослаблення негативних психічних установок, мотивів, стереотипів i формування нових сприятливих необхідних для подальшого проходження військової служби.

Психологічний супровід є складовою медико-психологічного супроводу. Він складається is «повсякденного психологічного супроводу» та «бойового психологічного супроводу».

Основними

завданнями

«повсякденного» медико-психологічного супроводу, слід вважати:

1. Діагностику психофізіологічного здоров'я кожного військовослужбовця;
2.

Вивчення

індивідуальнопсихологічних особливостей військовослужбовців;

3. Зміну рівня розвиненості або ступеню значущості деяких психічних властивостей чи станів особистості;

4. Аналіз психологічного (соціальнопсихологічного) клімату в родинах військовослужбовців;

5. Надання психологічної підтримки для налагодження родинно-побутових відносин;

6. Вивчення запитів, претензій, настрою у військових колективах 3 метою своєчасного реагування на них;

7. Вивчення морально-психологічного клімату у військових підрозділах 3 метою вирішення та прогнозування подальшого розвитку відносин міжособистісних конфліктних ситуацій;

8. Виявлення військовослужбовців 3 психологічними відхиленнями;

9. Організація заходів 3 корекції i підтримки психофізіологічного здоров'я особового складу, підвищення його психофізіологічної адаптивності;

10. Проведення навчально-практичних тренінгів 3 військовослужбовцям 3 метою надання їм знань i практичних навичок методів психофізіологічної само- та взаємодопомоги;

11. Налагодження взаємодії з медичною службою 3 питань підтримки психофізіологічного здоров'я особового складу.

Основними завданнями "бойового" медико-психологічного супроводу, визначимо:

1. Вивчення, оцінку i прогнозування психологічного стану військовослужбовців в ході службово-бойової підготовки та проведення військових операцій;

2. Оцінювання психологічного стану особового складу 3 метою визначення впливу на боєздатність (боєготовність);

3. Планування, аналіз та надання спрямованого коригуючого впливу на особовий склад;

4. Надання військовослужбовцям психологічної допомоги під час ведення бойових дій;

5. Соціально-психологічна реабілітація військовослужбовців, які повернулися із зони проведення бойових дій; 


\section{Питання психології}

6. Тренування в особового складу психологічної витривалості до ведення бойових дій в екстремальних умовах;

7. Виявлення військовослужбовців, які потребують психологічної допомоги та визначення iï обсягу, виявлення та негайне ізолювання військовослужбовців із ознаками важких психічних бойових розладів, які загрожують собі та оточуючим;

8. Налагодження взаємодії із медичною службою 3 питань надання допомоги та евакуації військовослужбовців, які мають ознаки важких бойових психічних розладів;

9. Проведення психокоригуючих та психотерапевтичних заходів 3 військовослужбовцями, які залишились у підрозділах [12].

Метою медико-психологічного супроводу $\epsilon$ досягнення і підтримування позитивного психо-емоційного стану військовослужбовців, що дозволяє ефективно виконувати навчально-бойові та бойові завдання [13].

Діяльність медико-психологічного супроводу спрямована, в першу чергу, не на дію, а на об'єкт та сутність військової психологічної діяльності - медикопсихологічний супровід військовослужбовців під час всієї служби, починаючи із військових комісаріатів.

Сутність психологічного супроводу полягає в формуванні у військовослужбовців такого психологічного ресурсу, який дозволить сприймати екстремальні умови ведення бойових дій як звичайні умови проходження військової служби: швидко ідентифікувати та аналізувати бойову обстановку, виокремлювати загрозливі фактори, своєчасно реагувати на них, зберігати необхідний рівень боєздатності та активності [14].

Останнім етапом медикопсихологічного супроводу, на нашу думку, слід вважати медико-психологічну реабілітацію, якої потребують, в залежності від інтенсивності ведення бойових дій, від 20 до 85\% військовослужбовців [15].

Робота 3 медико-психологічної реабілітації включає:

1. Психодіагностику з метою виявлення відхилень i порушень психіки у військовослужбовців;

2. Організацію своєчасного та повноцінного психотерапевтичної психологічного розвантаження;

3. Проведення традиційних (медикаментозних) та нетрадиційних (фізіотерапевтичних, фітотерапевтичних, гомеопатичних) методів.

Висновки і перспективи подальших досліджень. Таким чином, в ході проведеного дослідження, нами було виокремлено понятяя «медикопсихологічного супроводу», «психологічного відбору», «психопрофілактики» в системі моральнопсихологічного забезпечення. Обгрунтована та структурована концепція медикопсихологічного супроводу, яка може бути застосована для різних військових підрозділів. Схарактеризовано етапи медико-психологічного супроводу та обсяг дій, які повинні здійснюватися на кожному з них психологами (фахівцями 3 моральнопсихологічного забезпечення) та лікарями. Доведено, що досконало відпрацьований механізм психологічного супроводу важливий не тільки у повсякденній діяльності, а і під час ведення бойових дій, тому, що сприяє збереженню психічного здоров'я військовослужбовців, недопущенню виникнення панічних атак в екстремальних бойових умовах, формуванню стійкого ресурсного стану військовослужбовців, що дозволяє їм виконувати бойові (військово-професійні) завдання без дистресового перенавантаження.

\section{Список використаних джерел}

1. Удосконалення лікування та реабілітації військовослужбовців Збройних Сил України із бойовою психічною травмою: Метод.реком./[О.В. Друзь,О.Г. Сиропятов, М.І. Бадюк, О.М. Шемчук та ін.]. - К.: «МП Леся», 2015. - 52c, С.5-6.

2. Плотникова А. Г., Гахов А. М., Коваленко В. В. Анализ психоневрологической заболеваемости военнослужащих срочной службы. Науково-практичний журнал «Архів психіатрії», вип. 9 , К., 1995, C.-171-172.

3. Астапов Ю.Н. Вопросы психотерапии и психопрофилактики невротических расстройств у военнослужащих срочной службы вооруженных сил Украины. http://gvkg.kiev.ua/index.php/terapevtychnyi-tsyk1/126-klinika-psykhiatrychna-z-palatamy-dlia- 


\section{Питання психології}

narkolohichnykh-khvorykh/publikatsii-statti-naukovi-pratsi-stendovi-dopovidi/639-voprosy-psykhoterapyy-ypsykhoprofylaktyky-nevrotycheskykh-rasstroistv-u-voennosluzhashchykh-srochnoi-sluzhby-vooruzhennykhsyl-ukrayny (Режим доступа 15.07.2020).

4. Кутько И.И., Панченко О.А., Линев А.Н. Психопатологические последствия вооруженных конфликтов (литературно-аналитический обзор). Газета «Новости медицины и формации» 1 (525) 2015. C. 18-21.

5. Сыропятов О.Г. Медико-психологическое сопровождение специальных операций / О.Г. Сыропятов. - K. : O.Т. Ростунов, 2013. - 292 с. https://bookap.info/book/syropyatov_mediko_psihologicheskoe_soprovozhdenie_spetsialnyh_operatsiy/

6. Макаренко М.В. Психофизиологический отбор военных операторов / М.В. Макаренко. - К. : МО Украины, 1998. -350 с.

7. Діагностика індивідуально-психологічних властивостей особистості: Навчально-методичний посібник / А.Б. Неурова, О.С Капінус, Т.Л. Грицевич. - Львів: НАСВ, 2016 - 181 с, С 59-60. https://dovidnykmpz.info/wp-

content/uploads/2018/07/\%D0\%94\%D1\%96\%D0\%B0\%D0\%B3\%D0\%BD\%D0\%BE\%D1\%81\%D1\%82\%D $0 \% \mathrm{~B} 8 \% \mathrm{D} 0 \% \mathrm{BA} \% \mathrm{D} 0 \% \mathrm{~B} 0 . \mathrm{pdf}$

8. Шемчук О.M. Обгрунтування психодіагностичного інструментарію діагностування сформованості професійного мислення у майбутніх молодших спеціалістів - жіноквійськовослужбовців Державної прикордонної служби України. Теорія і практика сучасної психології: зб. наук. пр. 2020. Вип. 1. Т.3. С. 14-15 http://tpsp-journal.kpu.zp.ua/archive/1_2020/part_3/1-3_2020.pdf

9. Ушаков, И.Б. О профилактике психогенно обусловленных расстройств у военнослужащих / И.Б. Ушаков, В.И. Евдокимов, И.А. Беляева // Военно-медицинский журнал. - 2007. № 2. - С.49-52 $-208 \mathrm{c}$.

10. Мартинюк I. А. Патопсихологія. Навчальний посібник. - К.: Центр учбової літератури, 2008.

11. Саржевський С. Н. Психологія та патологія емоцій, волі, уваги : навчальнометодичний посібник для студентів 4 курсу медичних факультетів зі спеціальностей «Лікувальна справа» та «Педіатрія». - Запоріжжя, 2017. - 72 с.

12. Караяни А.Г., Сыромятников И.В. Прикладная военная психология. - СПб: Питер, 2006.

13. Баранов Е.Г., Кандыбович С.Л. Психологические основы подготовки военнослужащих к боевой деятельности. - М., 2000.

14. Сыромятников И.В. Организация психологической работы в войсковой части в мирное время. - M., 1999. 2001.

15. Чайка В.Г. Психология девиантного поведения военнослужащих и его профилактика. - М.,

\section{References}

1. Udoskonalennia likuvannia ta reabilitatsii viiskovosluzhbovtsiv Zbroinykh Syl Ukrainy iz boiovoiu psykhichnoiu travmoiu Metod. rekom. O.V. Druz O.H. Syropiatov M.I. Badiuk O.M. Shemchuk ta in.. - K. «MP Lesia» 2015. - 52s S.5-6.

2. Plotnikova A. G., Gakhov A. M., Kovalenko V. V. Analiz psikhonevrologicheskoj zabolevaemosti voennosluzhashhikh srochnoj sluzhby`. Naukovo-praktichnij zhurnal «Arkhiv psikhiatriyi», vip. 9 , K., 1995, S.-171-172.

3. Astapov Yu.N. Voprosy psikhoterapii i psikhoprofilaktiki nevroticheskikh rasstrojstv u voennosluzhashhikh srochnoj sluzhby vooruzhennykh sil Ukrainy. http://gvkg.kiev.ua/index.php/terapevtychnyi-tsykl/126-klinika-psykhiatrychna-z-palatamy-dlia-

narkolohichnykh-khvorykh/publikatsii-statti-naukovi-pratsi-stendovi-dopovidi/639-voprosy-psykhoterapyy-ypsykhoprofylaktyky-nevrotycheskykh-rasstroistv-u-voennosluzhashchykh-srochnoi-sluzhby-vooruzhennykhsyl-ukrayny (Access mode 15.07.2020).

4. Kut'ko I.I., Panchenko O.A., Linev A.N. Psikhopatologicheskie posledstviya vooruzhenny`kh konfliktov (literaturno-analiticheskij obzor). Gazeta «Novosti medicziny` i formaczii» 1 (525) 2015. S. 18-21.

5. Syropyatov O. G. Mediko-psikhologicheskoe soprovozhdenie speczial nykh operaczij / O. G. $\begin{array}{llllllll}\text { Syropyatov. } & - & \text { K. } & \text { : } & \text { O.T. } & \text { Rostunov, } 2013 . & - & \text { s. }\end{array}$ https://bookap.info/book/syropyatov_mediko_psihologicheskoe_soprovozhdenie_spetsialnyh_operatsiy/

6. Makarenko M.V. Psikhofiziologicheskij otbor voennykh operatorov / M.V. Makarenko. - K. : MO Ukrainy, 1998. $-350 \mathrm{~s}$.

7. Diagnostyka indyvidual 'no-psyxologichnyx vlastyvostej osobystosti: Navchal’no-metodychnyj posibnyk / A.B. Neurova, O.S Kapinus, T.L. Grycevych. - L'viv: NASV, 2016 - 181 s, S 59-60. https://dovidnykmpz.info/wp-

content/uploads/2018/07/\%D0\%94\%D1\%96\%D0\%B0\%D0\%B3\%D0\%BD\%D0\%BE\%D1\%81\%D1\%82\%D $0 \% \mathrm{~B} 8 \% \mathrm{D} 0 \% \mathrm{BA} \% \mathrm{D} 0 \% \mathrm{~B} 0 . \mathrm{pdf}$ 


\section{Питання психології}

8. Shemchuk O.M. Obgruntuvannya psyxodiagnostychnogo instrumentariyu diagnostuvannya sformovanosti profesijnogo my`slennya u majbutnix molodshyx specialistiv - zhinok-vijs 'kovosluzhbovciv Derzhavnoyi prykordonnoyi sluzhby Ukrayiny. Teoriya i praktyka suchasnoyi psy`xologiyi: zb. nauk. pr. 2020. Vy`p. 1. T.3. S. 14-15. http://tpsp-journal.kpu.zp.ua/archive/1_2020/part_3/1-3_2020.pdf

9. Ushakov, I.B. O profilaktike psikhogenno obuslovlennykh rasstrojstv u voennosluzhashhikh / I.B. Ushakov, V.I. Evdokimov, I.A. Belyaeva // Voenno-mediczinskij zhurnal. - 2007. \# 2. - S.49-52 $208 \mathrm{~s}$.

10. Martynyuk I. A. Patopsyxologiya. Navchal’nyj posibnyk. — K.: Centr uchbovoyi literatury, 2008. -

11. Sarzhevs 'kyj S. N. Psyxologiya ta patologiya emocij, voli, uvagy : navchal no-metodychnyj posibnyk dlya studentiv 4 kursu medychnyx fakul'tetiv zi special'nostej «Likuval'na sprava» ta «Pediatriya». Zaporizhzhya, 2017. - $72 \mathrm{~s}$.

12.Karayani A.G., Sy romyatnikov I.V. Prikladnaya voennaya psikhologiya. - SPb: Piter, 2006.

13. Baranov E.G., Kandybovich S.L. Psikhologicheskie osnovy podgotovki voennosluzhashhikh k boevoj deyatel'nosti. - M., 2000.

14. Sy`romyatnikov I.V. Organizacziya psikhologicheskoj raboty v vojskovoj chasti v mirnoe vremya. M., 1999.

15. Chajka V.G. Psikhologiya deviantnogo povedeniya voennosluzhashhikh i ego profilaktika. - M., 2001.

Резюме

Сыропятов О. Г. доктор медииинских наук, профессор, Государственное учреждения "Научно-исследовательское учреждения Министерства здравоохранения Украинь”"

Дзеружинская Н. А. доктор медичинских наук, профессор, Национальньй медицинский университет имени А.А. Богомольия Шемчук О. Н. Украинская военно-медииинская академия

Марущенко Е.Ю. Украинская военно-медииинская академия

\section{КОНЦЕПЦИЯ МЕДИКО-ПСИХОЛОГИЧЕСКОГО СОПРОВОЖДЕНИЯ} ВОЕНОСЛУЖАЩИХ ВООРУЖЕННЫХ СИЛ УКРАИНЫ

В статье рассмотрена конщепщия медико-психологического сопровождения военнослужащих Вооруженных Сил Украины. Содержание медико-психологического сопровождения состоит в вылвлении, анализе, оченке динамики сочиально-психологического климата в воинских коллективах, непосредственном наблюдении за психическим состоянием военнослужаших, оказании медикопсихологической помощи в сложных психологических условиях прохождения военной службы, наблюдении и корректировке сочиально-психологических процессов в военных коллективах.

Ключевые слова: медико-психологическое сопровождение; сочиально-психологический климат; клинико-психологический отбор; военнослужсащие.

\section{Summary \\ Syrpyatov O. Doctor of Sciences (Medicine), professor, \\ State Institution "Research Institution of the \\ Ministry of Health of Ukraine" \\ Dzerugzinska N. Doctor of Sciences (Medicine), professor, Bogomolets National Medical University \\ Shemchuk O. Ukrainian Military Medical Academy \\ Maruschenko K. Ukrainian Military Medical Academy \\ CONCEPT OF MEDICAL-PSYCHOLOGICAL SUPPORT OF MILITARY SERVANTS OF THE ARMED FORCES OF UKRAINE}

Introduction. Maintaining the mental health of servicemen is the most important social and medical joint task of the Command of the Medical Forces of the Armed Forces of Ukraine. Current events in the country show that the psychological health of servicemen, both in peacetime and in wartime, is not only a medical, psychological, but also a psychiatric problem.

Purpose. Development and substantiation of the concept of medical and psychological support of servicemen in order to prevent the occurrence and progression of mental disorders in servicemen of the Armed Forces of Ukraine.

Originality. The essence of psychological support is to form in servicemen such a psychological resource that will allow to perceive extreme conditions of hostilities as normal conditions of military service: quickly identify and analyze the combat situation, identify threatening factors, respond to them in a timely manner, maintain the required level of combat readiness. 


\section{Питання психології}

The activity of psychological support is aimed, first of all, not at the action, but at the object and essence of military psychological activity - psychological support of servicemen during the entire service, starting from the military commissariats.

Medical and psychological support of servicemen is an interdisciplinary dynamic system of social and medical and psychological actions aimed at adapting servicemen to the conditions of military service in various military formations, in peacetime and in wartime. Thanks to him, not only timely medical and psychological assistance is provided in crisis military-professional situations, but also mastering by servicemen of skills of providing psychological self- and mutual assistance in extreme (non-standard, stressful) conditions, which increases their stress resistance, professional adaptability, psychological endurance and accumulates. psychological resource of the serviceman's personality.

In the course of the research, we singled out the concepts of "medical and psychological support", "psychological selection", "psychoprophylaxis" in the system of moral and psychological support. Substantiated and structured concept of medical and psychological support, which can be applied to different military units. The stages of psychological support and the scope of actions to be performed on each of them by psychologists (specialists in moral and psychological support) and doctors are determined. It is proved that a well-established mechanism of psychological support is important not only in everyday activities, but also during hostilities, because it helps to preserve the mental health of servicemen, prevent panic attacks in extreme combat conditions, the formation of a stable resource state of servicemen. allows them to perform combat (military-professional) tasks without distress overload.

Conclusion. The article considers the concept of medical and psychological support of servicemen of the Armed Forces of Ukraine. The content of medical and psychological support is to identify, analyze, assess the dynamics of socio-psychological climate in military teams, direct monitoring of the mental state of servicemen, providing medical and psychological assistance in difficult psychological conditions of military service, monitoring and adjusting socio-psychological processes teams.

Key words: medical and psychological support; social and psychological climate; clinical and psychological selection; servicemen. 